\title{
Карнаухова А.,
}

доцент кафедри дошкільної освіти

Київського університету імені Бориса Грінченка,

кандидат педагогічних наук

a.karnaukhova@kubg.edu.ua

ORCID iD 0000-0001-6476-8084

\section{ЦИФРОВА ВІЗУАЛІЗАЦІЯ СТОРІТЕЛІНГУ ЯК МЕТОД ФОРМУВАННЯ КОМУНІКАТИВНОЇ КОМПЕТЕНТНОСТІ МАЙБУТНІХ ВИХОВАТЕЛІВ}

\begin{abstract}
У статті проаналізовано сторітелінг як метод формування комунікативної компетентності майбутніх вихователів. Сторітелінг розглядається як метод формування комунікативної компетентності студентів та як засіб цисрової візуалізації. Він дає змогу реалізовувати освітній процес у Педагогічному інституті Київського університету імені Бориса Грінченка з широким використанням мультимедійних форм подачі навчального матеріалу. Висвітлено завдання сторітелінгу, визначено основні елементи розповідання історій, програмні засоби й інструменти створення цифрової візуалізації сторітелінгу. Розкрито діяльність Центру інноваційних освітніх технологій (ICR) у практичній підготовці майбутніх вихователів.
\end{abstract}

Ключові слова: комунікативна компетентність, майбутні вихователі, сторітелінг, цифрова візуалізація.

(с) Карнаухова А., 2021

( ) Київський університет імені Бориса Грінченка, 2021

Вступ. Головним напрямом модернізації освіти є виховання особистості, яка прагне до максимальної реалізації своїх можливостей, відкритої для сприйняття нових знань, здатної на усвідомлений та відповідальний вибір у різних життєвих ситуаціях. Для здійснення цього завдання важливо навчити майбутніх вихователів застосовувати сучасні методи формування комунікативної компетентності під час практики та роботи в закладі дошкільної освіти. Комунікативна компетентність передбачає володіння всіма видами засобів комунікації, основами культури усного та писемного мовлення, базовими вміннями і навичками використання комунікативних засобів у різних сферах і ситуаціях спілкування. Також це поняття включає оволодіння необхідним набором не тільки мовленнєвих знань, а й умінь у галузі комунікативного аспекту будь-якої професійної діяльності, практичного використання засобів комунікації, що необхідно для формування соціально активної особистості, яка орієнтується у сучасному світі.

Аналіз останніх досліджень і публікацій. У педагогіці метод сторітелінгу відомий ще з 90-х років XX ст. Показовими роботами $є$ закордонні праці Egan K. "Teaching as storytelling" та Rossiter M. "Narrative and Stories in Adult Teaching and Learning".
В Україні дослідженням методу сторітелінгу почали займатися нещодавно і на сьогодні він вважається інноваційним в освіті. У дошкільній освіті сторітелінг вивчали К. Крутій, Л. Зданевич; використання сторітелінгу в професійній підготовці майбутніх педагогів - С. Паламар, М. Науменко, Т. Черненко; у сучасній медіаіндустрії - Г. Синоруб, В. Шевченко; створення мультимедійних платформ - Л. Василик, Д. Тужанський.

Мета статті обгрунтувати можливості використання цифрової візуалізації сторітелінгу як методу формування комунікативної компетентності майбутніх вихователів.

Завдання:

- проаналізувати сутність поняття «сторітелінгу» як методу формування комунікативної компетентності;

- схарактеризувати діяльність Центру інноваційних освітніх технологій (ICR) у практичній підготовці майбутніх вихователів.

Виклад основного матеріалу. Мовлення дитини дошкільного віку є головним інструментом, за допомогою якого дошкільник встановлює контакт із довкіллям і завдяки якому відбувається його соціалізація. У процесі різнобічного спілкування дитина дошкільного віку пізнає природний, предметний і соціальний світ у його цілісності й різноманітності, формує та розкриває власний внутрішній світ, свій 
образ «Я», засвоює та створює культурні цінності, $€$ при цьому активним суб’єктом взаємодії.

Як зазначає Г.М. Гич, мова є важливим компонентом аудіальної культури особистості та слугує засобом спілкування людей і впливу на них. Важливим засобом майбутнього вихователя $\epsilon$ аудіальна форма навчання, яка дає змогу засвоювати матеріал за рахунок аудіальної сприйнятливості дітей.

Тобто, в основі понять із загальним коренем “audi-" лежить здатність людини чути або особливим чином сприймати звукове середовище (Гич Г., 2015). Наразі ми використовуємо нові методики, які допоможуть майбутнім вихователям формувати мовленнєву компетентність (фонетика, лексика, граматика) у дітей дошкільного віку через впровадження в освітній процес методів, що дають можливість говорити, писати і слухати.

Таким чином, актуальним питанням у підготовці майбутнього вихователя під час навчання $€$ використання інформаційно-комунікаційних технологій в освітньому процесі закладу вищої освіти, зокрема сторітелінгу.

Саме поняття «сторітелінг» походить від англ. "story" (історія) та "telling" (розказувати). Розробником сторітелінгу був Девід Армстронг, який використовував зазначений метод у своїй корпорації. Саме цю методику він описав у книзі "MBSA: Managing by Storying Around" (Armstrong D., 1992). У процесі створення сторітелінгу Армстронг врахував такий психологічний фактор: розповідь значно легше сприймається, вона цікавіша, ніж логічні доводи та сухі міркування.

До сторітелінгу належить все, що ви чуєте або бачите навкруги: передачі по радіо, розважальні програми по телебаченню, казки для дітей і т. ін. Слід зазначити, що сторітелінг - це не завжди веселі розповіді. За емоційною забарвленістю вони можуть бути сумними, страшними, смішними, кумедними, зворушливими, але спільне в них те, що всі вони викликають емоції.

Аналіз досліджень свідчить про те, що через 72 години людина в середньому пам'ятає лише $10 \%$ від почутого. Якщо ж додати візуальну складову, то цей показник зростає до $65 \%$. Одним із найефективніших засобів вплинути на емоції лишається побачити все на власні очі або ж картинку. За даними різних досліджень, візуальні зображення впливають на нас істотно, становлячи левову частину всього обсягу інформації, яку ми споживаємо - від 60 \% до 90 \% (Кнюпа Ю., 2020).

Для кращого сприйняття інформації професійна скрайберка Ю. Кнюпа пропонує такі ефективні прийоми візуалізації: обов'язково має бути персонаж, малюнок на звичайному папері (або додаток Notebloc (доступний і в AppStore, i в Play Market); зав'язка - розвиток подій - кульмінація - розв'язка; використання базових кольорів; вплив слова.
М. Роуді у посібнику «Скетчноутінг. Посібник із візуалізації ідей» стверджує, що найважливіше у картинці - це ідеї, а не оздоблення, дослівно “ideas, not art” (Роуді М., 2016).

Отже, з огляду на зазначене вище основними завданнями сторітелінгу є:

- оволодіння увагою читача або глядача;

- викликання довіри;

- створення асоціації;

- стимулювання емоційної сфери та виклик співпереживання;

- запам'ятовування історії.

Інтегрований курс «Поліхудожня освіта дітей дошкільного віку» викладається студентам 3 курсу освітнього рівня: перший (бакалаврський), спеціальності 013 «Початкова освіта» додаткова спеціалізація «Дошкільна освіта» в Педагогічному інституті Київського університету імені Бориса Грінченка. Метою інтегрованого курсу є формування комунікативної компетентності та володіння педагогічним інструментарієм включення дитини у різні види художньої діяльності.

Основними завданнями навчальної дисципліни є формування загальних і фахових компетентностей, зокрема:

- здатність діяти соціально відповідально, поважати різноманітність і мультикультурність у процесі педагогічної взаємодії;

- здатність до розвитку в дітей раннього і дошкільного віку базових якостей особистості;

- здатність до організації і керівництва ігровою, художньо-мовленнєвою та художньопродуктивною діяльністю дітей раннього і дошкільного віку.

Зміст розподілено по модулях, у яких розкриваються особливості поліхудожньої освіти дошкільнят у закладі дошкільної освіти:

- змістовий модуль 1. Теоретичні основи поліхудожньої освіти дітей дошкільного віку;

- змістовий модуль 2. Теоретичні засади ознайомлення дітей з образотворчим мистецтвом;

- змістовий модуль 3. Технології ознайомлення дітей з образотворчим мистецтвом;

- змістовий модуль 4. Театральне мистецтво як складова дошкільної освіти;

- змістовий модуль 5. Музичне мистецтво як складова дошкільної освіти.

Для реалізації змістового модуля «Театральне мистецтво як складова дошкільної освіти» інтегрованого навчального курсу «Поліхудожня освіта дітей дошкільного віку» ми використовуємо інноваційні методи, що сприяють розумінню студентами значущості цифрової візуалізації сторітелінгу як методу формування комунікативної компетентності. Так, у Педагогічному інституті Київського університету імені Бориса Грінченка 
відкрито Центр інноваційних освітніх технологій (ICR) завдяки проєкту «Модернізація педагогічної вищої освіти 3 використання інноваційних інструментів викладання» (MoPED) програми «С Еразмус».

У центрі під час практичних та лабораторних занять майбутні вихователі оволодівають умінням створювати історії так, аби всі слухали затамувавши подих. Для кожного студента важливо навчитися розповідати історії на аудиторію, щоб мати можливість бачити реакцію. Крім того, студенти вчаться розв'язувати проблемні питання, розкривати ідеї, користуватися хмарою слів, складати комікси, інтелект-карти, інтерактивні книги, мультфільми, відео, колажі.

Наприклад, студенти отримують завдання: скласти розповідь, вживаючи не менше 10 слів зі словничка чи хмари слів з теми, яку вивчаємо (Земля, природа, дерева, квіти, небо, сонце тощо); або вони можуть відзняти відеоролик, намальований мультфільм чи представити набір слайдів, обов'язково застосовуючи музичний супровід. При цьому використовуємо для хмари слів такі інструменти: WordArt, WordLtOut, WordCloud. pro, Word Cloud Generation.

Для створення цифрових історій ми користуємося такими програмами:

- Closr - дає можливість на великому зображенні виділяти мітками певні зображення і додавати до них надписи;

- ZooBurst - за допомогою неї можна будьяку сторінку тексту, створену в такому сервісі, переглянути під будь-яким кутом у 3D-просторі;

- Narrable - використовується, коли для створення історії необхідно завантажити зображення і до них прикріпити звуковий файл («озвучку»);

- Storify - цей сервіс дає можливість створювати цілі статті або пости в мережі «Інтернет», де збираються тексти, зображення та відеоджерела;

- Metta - програма для створення відеолекцій та цифрових історій на основі тексту, зображень і відео;

- PowToon - сервіс анімованих презентацій 3 набором шаблонів для роботи і великою бібліотекою зображень та ефектів;

- Moovly - сервіс для створення анімованих презентацій з елементами скрайбінгу;

- Wideo i GoAnimate - програми для створення анімованих відеороліків (перша з використанням готових шаблонів);

- Cервіси Chogger i ToonDoo призначені для створення коміксів, у тому числі - мальованих коміксів та коміксів на основі власних фотографій і картинок або галереї готових персонажів, фонів та предметів.

Для того, щоб урізноманітнити сторітелінг в освітньому процесі закладу вищої освіти, С. Паламар та М. Науменко визначають такі сучасні інструменти:

- Storyjumper (https://www.storyjumper.com/);

- Ourboox (https://www.ourboox.com/);

- Piktochart (https://piktochart.com/);

- Twine (https://twinery.org/);

- Wix.com (https://wix.com/);

- Canva (https://www.canva.com/);

- Pixton (https://www.pixton.com/).

Автори наголошують на тому, що «....перераховані інструменти $€$ мультифункціональними, а їхнє використання не має обмеження на сферу застосування. Перевагою цих інструментів є умовна безкоштовність» (Паламар С., Науменко М., 2019).

Метод сторітелінгу, на наш погляд, сприяє формуванню у студентів орієнтовної основи поведінки у мовних ситуаціях; ознайомленню студентів з варіантами мовних дій, умінь їх комбінувати і знаходити нові рішення. У майбутніх вихователів виробляється впевненість у володінні прийомами, заснованими на особистому досвіді; формується досвід вираження своєї особистісної позиції в спілкуванні, адекватної самооцінки «продуктів спілкування», розвивається уява та вміння презентувати себе.

На практичних заняттях важливо, щоб студенти навчилися не тільки розповідати, а й створювати історії. Сторітелінг може застосовуватися i як метод навчання, і як метод переконання, тому ми ознайомюємо студентів з можливостями використання історій у їхніх виступах. Майбутні вихователі розказують історії про прочитані книги (тут надзвичайно важливо дати можливість вибрати таку книгу самому). У подальшому можна проводити заняття зі спільного придумування таких історій, вибудовування своїх власних розповідей за ілюстраціями або малюнками (студенти - візуали (сприйняття малюнків) поступово ставатимуть аудіалами через озвучування власних історій).

Висновки. Таким чином, на формування комунікативної компетентності майбутніх вихователів впливають різноманітні сучасні інтерактивні технології, зокрема використання сторітелінгу, доповненого цифровою візуалізацією.

у подальшому перспективу дослідження вбачаємо у розробці методики формування комунікативної компетентності майбутніх вихователів за допомогою цифрової візуалізації сторітелінгу. 


\section{ДЖЕРЕЛА}

1. Armstrong D. MBSA: Managing by Storying Around. New York: Doubleday Currency, 1992. 272 p.

2. Бондаренко H. Storytelling як комунікаційний тренд і всепредметний метод навчання. Молодь і ринок. 2019. № 7 (174). С. 130-135.

3. Гич Г.М. Сторітелінг як інноваційна методика формування мовної компетентності учнів 3НЗ. Науковий вісник. Педагогічні науки. 2015. № 4 (51). С. 188-191. URL: http://nbuv.gov.ua/UJRN/Nvmdup 4. Герасименко О. Сторителлинг - эффективный вариант неформального обучения. URL: https:// leanoffice.ru/mancult/storylearn.html

5. Кнюпа Ю. Як використати силу візуального сторітелінгу для поширення соціальних ідей? 7 порад від професійної скрайберки. URL: https://bhfamily.org/yak-vykorystaty-sylu-vizualnogo-storitelingudlya-poshyrennya-sotsialnyh-idej

6. Крутій К., Зданевич Л. Сторітелінг: мистецтво розповідання, або Як зацікавити й мотивувати дітей. Дошкільне виховання. 2017. № 7. С. 2-7.

7. Науменко М.С. Сучасні освітні інструменти у формуванні конкурентоспроможного фахівця дошкільної освіти «Освіта XXI століття: теорія, практика, перспективи»: матеріали Першої міжнародної науково-практичної Інтернет-конференції. Дидактика: теорія і практика. К., 2019. С. $205-207$. 8. Паламар С., Науменко М. Сторітелінг у професійній підготовці майбутніх педагогів: сучасні інструменти. Електронне наукове фахове видання «Відкрите освітнє е-середовище сучасного універcumemy». 2019. № 7. C. 48-55. URL: https://openedu.kubg.edu.ua/journal/index.php/

9. Роуді М. Скетчноутінг. Посібник із візуалізації ідей. 2016. 224 с.

10. Evans E. Character, Audience Agency and Transmedia Storytelling. Media, Culture \& Society. 2008. Vol. 30. № 2. P. 39-47.

\section{REFERENCES}

1. Armstrong, D. (1992). MBSA: Managing by Storying Around. New York Doubleday Currency, 272 p. [in English].

2. Bondarenko, N. (2019). Storitelinh yak komunikatsiinyi trend i vsepredmetnyi metod navchannia [Storytelling as a Communication Trend and an All-Subject Teaching Method]. Molod i rynok, No. 7 (174), pp. 130-135 [in Ukrainian].

3. Hych, H. M. (2015). Storitelinh yak innovatsiina metodyka formuvannia movnoi kompetentnosti uchniv ZNZ [Storytelling as an Innovative Method of Forming the Language Competence of Sstudents of CEE]. Naukovyi visnyk. Pedahohichni nauky (electronic journal), No. 4 (51), pp. 188-191 [in Ukrainian]. http://nbuv.gov.ua/UJRN/Nvmdup

4. Gerasimenko, O. Storitelling - effektivnyi variant neformalnogo obucheniia [Storytelling as an Effective Form of Nnon-formal Learning] [in Russian].

https://leanoffice.ru/mancult/storylearn.html

5. Kniupa, Yu. (2020). Yak vykorystaty sylu vizualnoho storitelinhu dlia poshyrennia sotsialnykh idei? 7 porad vid profesiinoi skraiberky [How to Use the Power of Visual Storytelling to Spread Social Ideas? 7 tips from a professional scriber] [in Ukrainian].

https://bhfamily.org/yak-vykorystaty-sylu-vizualnogo-storitelingu-dlya-poshyrennya-sotsialnyh-idej

6. Krutii, K., Zdanevych, L. (2017). Storitelinh: mystetstvo rozpovidannia, abo yak zatsikavyty i motyvuvaty ditei [Storytelling: the art of storytelling, or how to interest and motivate children]. Doshkilne vykhovannia, No. 7, pp. 2-7 [in Ukrainian].

7. Naumenko, M. S. (2019). Suchasni osvitni instrumenty u formuvanni konkurentospromozhnoho fakhivtsia doshkilnoi osvity "Osvita XXI stolittia: teoriia, praktyka, perspektyvy" [Modern Educational Tools in the Formation of a Competitive Specialist in Preschool Education "Education of the 21st century: theory, practice, prospects"]. Materialy Pershoi mizhnarodnoi naukovo-praktychnoi Internet-konferentsii, Dydaktyka: teoriia i praktyka, pp. 205-207 [in Ukrainian].

8. Palamar, S., Naumenko, M. (2019). Storitelinh u profesiinii pidhotovtsi maibutnikh pedahohiv: suchasni instrumenty [Storytelling in Professional Training of Future Teachers: modern tools]. "Vidkryte osvitnie e-seredovyshche suchasnoho universytetu" ["Open educational e-environment of a modern university"], (electronic journal), No. 7, pp. 48-55 [in Ukrainian].

https://openedu.kubg.edu.ua/journal/index.php/

9. Roudi, M. (2016) Sketchnoutinh. Posibnyk iz vizualizatsii idei [Sketchouting. A guide to visualizing ideas]. 224 p. [in Ukrainian].

10. Evans, E. (2008). Character, Audience Agency and Transmedia Storytelling. Media, Culture \& Society, Vol. 30, No. 2, pp. 39-47 [in English]. 


\section{Карнаухова А. \\ ЦИФРОВАЯ ВИЗУАЛИЗАЦИЯ СТОРИТЕЛЛИНГА КАК МЕТОД ФОРМИРОВАНИЯ КОММУНИКАТИВНОЙ КОМПЕТЕНТНОСТИ БУДУЩИХ ВОСПИТАТЕЛЕЙ}

В статье проанализирован сторителлинг как метод формирования коммуникативной компетентности будущих воспитателей. Сторителлинг рассматривается как метод формирования коммуникативной компетентности студентов и как средство иифровой визуализации. Он позволяет реализовывать образовательный процесс в Педагогическом институте Киевского университета имени Бориса Гринченко с широким использованием мультимедийных форм подачи учебного материала. Освещены задачи сторителлинга, определены основные элементы рассказывания историй, программные средства и инструменты создания иифровой визуализации сторителлинга. Раскрыта деятельность Центра инновационных образовательных технологий (ICR) в практической подготовке будущих воспитателей.

Ключевые слова: коммуникативная компетентность, будущие воспитатели, сторителлинг, цифровая визуализачия.

\section{A. Karnaukhova \\ DIGITAL VISUALIZATION OF STORYTELLING AS A METHOD OF FORMATION OF COMMUNICATIVE COMPETENCE OF FUTURE EDUCATORS}

The proposed article analyses storytelling as a method of forming the communicative competence of future educators. Storytelling is seen as a method of improving students' communicative competence and as a means of digital visualization. However, the concept of communicative competence includes mastering the necessary set of not only speech knowledge but also skills in the communicative aspect of any professional activity, as well as the practical use of communication tools necessary for the formation of a socially active personality oriented in the modern world. We are currently using new techniques that will help future educators to form speech competence (phonetics, vocabulary, grammar) of preschool children through the introduction into the educational process of methods that allow: to speak, write and listen. This method allows to implement the educational process at the Pedagogical Institute of Borys Grinchenko Kyiv University with extensive use of multimedia forms of teaching material on the example of the content module "Theatrical Art as a Component of Preschool Education", integrated course "Polyart Education of Preschool Children" for students majoring in 013 "Primary Education", specialization "Preschool Education". Students learn to solve problems, reveal ideas, use a cloud of words, compose comics, intelligence maps, interactive books, cartoons, videos, collages. The tasks of storytelling are covered: to capture the attention of the reader or viewer; to inspire trust; to create associations; to stimulate the emotional sphere and evoke empathy; to memorize stories. The main elements of storytelling and the main software tools for creating digital visualization of storytelling are identified. The essence of the concept of "storytelling" as a method of formation of communicative competence is substantiated and analysed. The activities of the Center for Innovative Educational Technologies (ICR) in the practical training of future educators are revealed and a list of tools and programmes such as Closr, ZooBurst, Narrable, Storify, Metta, PowToon, Moovly, Wideo and GoAnimate, Chogger and ToonDoo, used in the work with students are presented.

Key words: communicative competence, future educators, partnering, Digital Visualization.

Стаття надійшла до редакції 10.03.2021 p.

Прийнято до друку 18.03.2021 p. 